\title{
Polyacrylamide gel electrophoresis of soybean seed proteins
}

\author{
W. LASSOCIŃSKI and J. S. KNYPL
}

Laboratory of Plant Growth Regulators, University of Eódź

(Received: July 5, 1978)

\begin{abstract}
Four major and 14 minor protein bands were detected when total salt soluble proteins of soybean (Glycine max cultivar Warszawska) seed were subjected to polyacrylamide gel electrophoresis under nondissociating conditions, and 16 protein bands were detected under dissociating conditions. Molecular weights of three major protein fractions in PAGE SDS were determined for around 18500,36000 and 80000 daltons.
\end{abstract}

\section{INTRODUCTION}

Two major storage protein fractions of legume seeds, legumins and vicillins (O s b o r n e, 1924), are now referred to most commonly by sedimentation coefficients, $11 \mathrm{~S}$ and $7 \mathrm{~S}$, respectively (Derbyshire et al., 1976). Minor fractions of smaller and larger globulins, 2-4S and 15-18S, are also found in the protein extracts (cf. K ulk and Grzesi u k, 1978). The latter ones seem to be products of association during purification, as several legume seed globulins are known to undergo either salt- or pH-dependent reversible polymerization (Cat simpoolas et al., 1969; Koshiyama, 1968; Roberts and Briggs, 1965; S t ockman et al., 1976; Wolf, 1970).

Salt extractable protein of soybean seed had been fractionated into three classes: $11.8 \mathrm{~S}$ (glycinin), $7.5 \mathrm{~S}$ and $2.8 \mathrm{~S}$, by sucrose density gradient centrifugation at high ionic strength $(I=0.5)$. The $7.5 \mathrm{~S}$ protein peak considerably diminished at low ionic strength $(I=0.1)$ with simultaneous formation of a $9 \mathrm{~S}$ protein. Only the $11.8 \mathrm{~S}$ protein behaved as a homogenous fraction when it had been subjected to polyacrylamide gel electrophoresis (PAGE) under nondissociating conditions, whereas the others were found to be heterogenous ( $\mathrm{Hill}$ and $\mathrm{Breidenbach}$, 1974). 
Molecular weight (MW) for glycinin and 7S globulins of soybean have been reported to be in a range of 309 000-380 000 and 105000-330 000, respectively (cf. Derbyshire et al., 1976). The glycinin molecule seems to be built up of 12 subunits with equimolar amounts of acidic (MW 37000 ) and basic (MW 22000 ) ones (C a t s i m pool a s et al., 1967; Catsimpoolas 1969); both acidic and basic subunits were fractionated into several bands by techniques of isoelectric focussing and PAGE (cf. D e r b y s hir e et al., 1976). Different molecular weights have been assigned to subunits of the $7 \mathrm{~S}$ globulin of soybean, the values differing as much as 23000 and 35000 as determined by sedimentation analyses, and 23000,51000 and 81000 as determined by PAGE of urea dissociated preparations ( $c f . \mathrm{D}$ e r b y s hir e et al., 1976). There is no doubt that such large discrepancies were due to different procedures of purification resulting in the non-identity of the final protein preparations (cf. $\mathrm{Kulka}$ and Grzesiuk, 1978).

The aim of this study was to test how many bands could be detected in extracts of total soybean seed proteins subjected to electrophoresis under dissociating conditions (PAGE SDS).

\section{MATERIAL AND METHODS}

\section{Protein extraction}

Seeds of Glycine max Merr. cultivar Warszawska were obtained from IHAR, Radzików nr. Warsaw. The seeds were harvested in 1976, and used for analyses in spring 1977. Vigour of the seeds as measured by electroconductivity of steep water and germinability at low temperature (K n y p l, 1978) was rather low. Maximum germination at $25{ }^{\circ} \mathrm{C}$ and $10{ }^{\circ} \mathrm{C}$ was around $70 \%$ and $35 \%$, respectively.

Dehulled seeds were cracked in a Waring blendor and milled to a fine powder. Lipids were discarded with $n$-hexane (16 ml per $\mathrm{g}$ of meal) for $16 \mathrm{~h}$ at room temperature. Protein was extracted twice with $0.02 \mathrm{M}$ phosphate buffer, $\mathrm{pH} 7.4$, containing $2.5 \%$. $\mathrm{w} / \mathrm{v})$ of $\mathrm{NaCl}$ and $0.01 \mathrm{M}$ 2-mercaptoethanol (S a b i r et al., 1973). Each extraction was conducted at room temperature for $45 \mathrm{~min}$ at a meal to solvent ratio of $1: 10$ $(\mathrm{w} / \mathrm{v})$ and continuous shaking. After clearing by centrifugation at $4500 \mathrm{~g}$ for $20 \mathrm{~min}$, the supernatant was subjected to gel chromatography.

\section{Gel chromatography}

The salt soluble proteins $(150-180 \mathrm{mg})$ were fractionated at $6{ }^{\circ} \mathrm{C}$ on a $2.6 \times 90 \mathrm{~cm}$ column K26/100 (Pharmacia, Uppsala) packed with Sephadex G-200. The proteins were eluted by downward flow of $2.5 \%$ 
(w/v) $\mathrm{NaCl}$ solution in $0.02 \mathrm{M}$ phosphate buffer, $\mathrm{pH} 7.4$, containing $0.01 \mathrm{M} 2$ 2-mercaptoethanol and $0.02 \%$ sodium azide as a bacteriostatic agent. Five $\mathrm{ml}$ fractions were collected each $20 \mathrm{~min}$. For the estimation of MW, the column was calibrated by determining the elution volumes $\left(\mathrm{V}_{\mathrm{e}}\right)$ of standard proteins. The regression between $\mathrm{V}_{\mathrm{e}} / \mathrm{V}_{\mathrm{o}}$ and the log of the molecular weight was highly significant.

Polyacrylamide gel electrophoresis

In nondissociating discontinuous PAGE system the procedure of D a vis (1964) with $5 \%(\mathrm{w} / \mathrm{v})$ acrylamide $(5 \% \mathrm{~T} ; 2.6 \% \mathrm{C}){ }^{*}$ in the running gel at $\mathrm{pH} 8.9$ (Tris-glycine buffer), and $2.5 \%$ acrylamide in the spacer gel was used. $100 \mu \mathrm{l}$ aliquots of crude extract or eluates from a column of Sephadex G-200, containing 250-350 $\mu \mathrm{g}$ of protein, were applied to the spacer gel. Cathode buffer was twice as much concentrated as anode one. Electrophoresis was carried out for $3.5 \mathrm{~h}$ at $4 \mathrm{~mA}$ per tube, after initial $15 \mathrm{~min}$ period at $2 \mathrm{~mA}$ per tube. Protein bands were visualized by positive staining with $0.04 \%$ Coomassie Brillant Blue G-250 in 3.5\% perchloric acid (R e i s n e r et al., 1975).

The running gel in the dissociating system contained $10 \%$ acrylamide with $2,7 \%$ N, $\mathrm{N}^{\prime}$-methylebisacrylamide cross linker, and $1.0^{\%} \%$ SDS (sodium laurylsulphate) in $0.1 \mathrm{M}$ phosphate buffer, pH 7.0 (Eastman SDS). Protein samples were boiled for $5 \mathrm{~min}$ in $0.01 \mathrm{M}$ phosphate buffer containing $1 \%$ SDS, $1 \%$ 2-mercaptoethanol and $8 \mathrm{M}$ urea, and dialyzed for $12 \mathrm{~h}$ against $0.01 \mathrm{M}$ phosphate buffer supplemented with $0.1 \%$ SDS and $0.1 \%$ 2-mercaptoethanol. $20 \mu \mathrm{l}$ aliquots containing 18-32 $\mu \mathrm{g}$ of protein were applied to the gel. $0.1 \mathrm{M}$ phosphate buffer containing $1 \%$ SDS at pH 7.0 was used as electrode buffer. Electrophoresis was carried out for $12 \mathrm{~h}$ at $2 \mathrm{~mA}$ per tube. Protein bands were stained with $0.25 \%$ Coomassie Brillant Blue G-250 in a mixture of $7 \%$ acetic acid in $50 \%$ methanol.

Molecular weights were read from a curve of relative electrophoretic mobilities $(\mathrm{Rm})$ of protein standards: bovine serum albumin, MW 68000 ; ovoalbumin, MW 45 000; chymotrypsinogen, MW 27500 ; RNase A, MW 13 700; and cytochrome C, MW 11 700. All protein standards were obtained from Serva Feinbiochemica (Heidelberg) and reagents for PAGE and PAGE SDS were obtained from Eastman Kodak and Co., Rochester, N. Y.

Gels were scanned at $600 \mathrm{~nm}$ in Carl Zeiss (Jena) densitometer Eri $65 \mathrm{~m}$ with a home made attachement for polyacrylamide slabs.

* $\mathrm{T}=\frac{\mathrm{a}+\mathrm{b}}{\mathrm{m}} \cdot 100 \% ; \mathrm{C}=\frac{\mathrm{b}}{\mathrm{a}+\mathrm{b}} \cdot 100 \%$, where $\mathrm{a}=$ acrylamide $(\mathrm{g}) ; \mathrm{b}=$ bisacryl-

amide $(\mathbf{g}) ; \mathrm{m}=$ volume of buffer $(\mathrm{ml})$. 


\section{RESULTS}

Four protein fractions were eluted from a column of Sephadex G-200. Fraction A, eluting in $\mathrm{V}_{\mathrm{o}}$ (MW 540000 daltons), was heavily contaminated with non protein compounds as inferred from a low A 280/A $260 \mathrm{~nm}$ ratio (Table 1). Majority of protein was eluted in a fraction B (MW around 350000$)$, followed by minor fraction $\mathrm{C}$ and $\mathrm{D}\left(\mathrm{MW}^{\prime} \mathrm{s}\right.$ around 100000 and 22000 , respectively). There were also fractions $e$ and $f$ which overlapped and contained low molecular non protein material. Fractions A and B overlapped.

\section{Table 1}

UV absorbance characteristics and apparent molecular weight of salt extractable soybean seed protein fraction separated on a Sephadex G-200 column. In parentheses results of similar analyses carried out by Sabir, Sosulski and MacKenzie (1973) are given. Fractions A and B in this study overlapped

\begin{tabular}{|c|c|c|c|}
\hline Fraction & $\lambda \max , \mathrm{nm}$ & $\frac{\mathrm{A} 280}{\mathrm{~A} 260}$ & Apparent MW, daltons \\
\hline A & $260(260)$ & $0.70(0.90)$ & $>540000(600000)$ \\
B & $278(280)$ & $1.54(1.30)$ & $350000(400000)$ \\
C & $276(275)$ & $1.70(1.00)$ & $100000(120000)$ \\
D & $270(275)$ & $1.00(1.10)$ & $22000(30000)$ \\
\hline
\end{tabular}

Aliquots of fractions A-D were subjected to PAGE under nondissociating conditions. The gels were intentionally overloaded to reveal minor protein fractions. 18 protein bands were detected in a crude extract, the major fractions being bands No. 3, 4, 7 and 8 (Fig. 1). These bands possibly correspond to bands No. 1-4 in a similar study performed by $\mathrm{Hill}$ and $\mathrm{Breide} \mathrm{nbach}(1974)$ who detected only 5 fractions. The
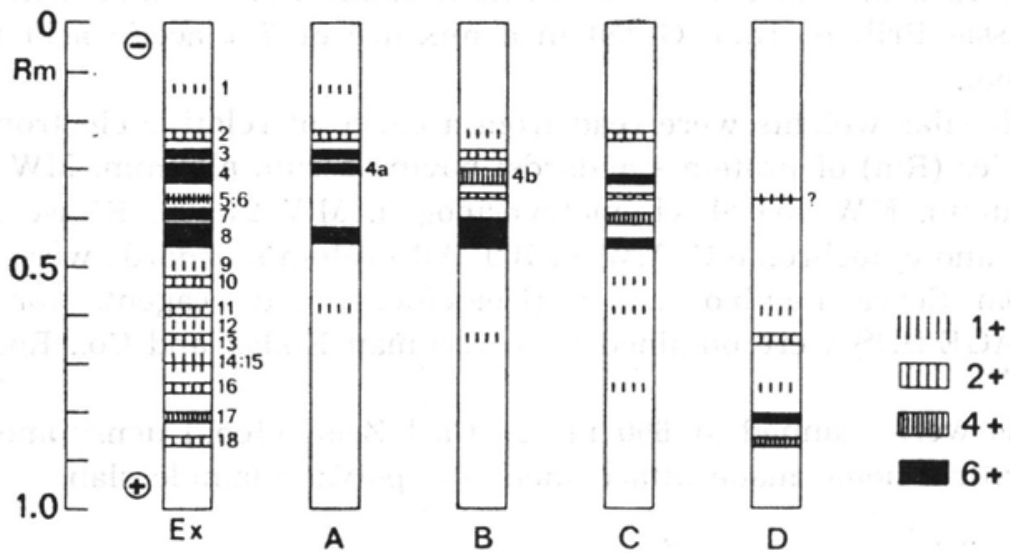

Fig. 1. Electrophoretic patterns of salt extractable proteins under nondissociating conditions. Ex - total extract; A, B, C, and D - Sephadex G-200 fractions 
bands No. 4 and 8 were present in fractions A, B and C. The band No. 4 seems to be heterogenous as it tends to separate to bands No. 4a and $4 \mathrm{~b}$ in the fractions $\mathrm{A}$ and $\mathrm{B}$, respectively.

Band No. 7 was not detected in the fraction A. Bands 8 and 17 were the major ones in fractions $\mathrm{C}$ and $\mathrm{O}$, respectively (Fig. 1).

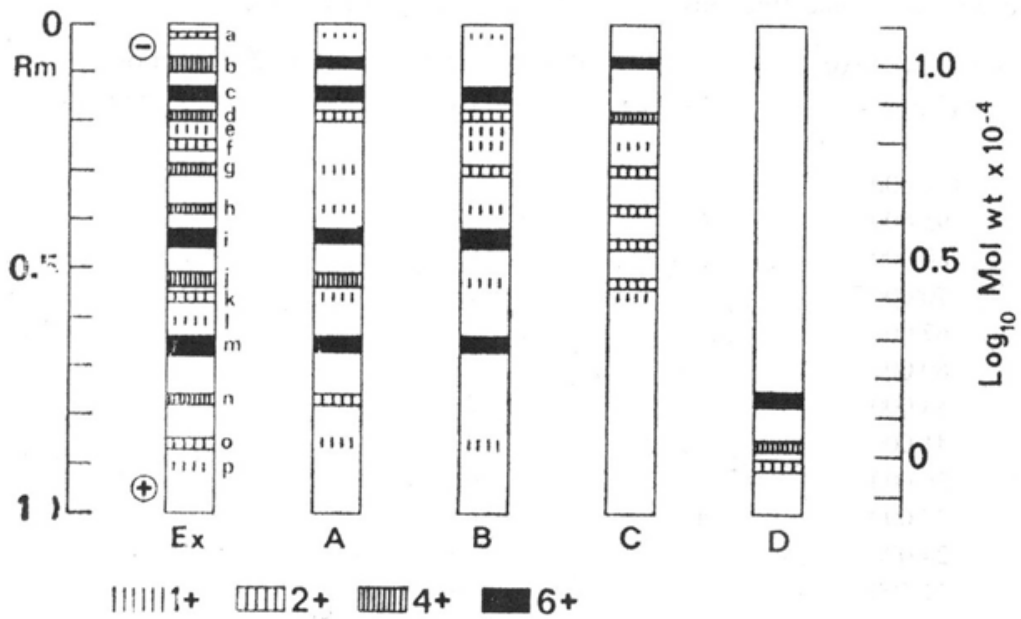

Fig. 2. Electrophoretic patterns of salt extractable proteins under dissociating conditions (SDS PAGE). Abbreviations as in Fig. 1

Sixteen bands $a-p$ were detected when total protein extract was subjected to PAGE SDS (Fig. 2). The main bands were the bands $c, i$ and $m$, followed by $b, d$ and $j$ (Fig. 3). The band $b$ (MW 95000 ) was detected in fractions $\mathrm{A}$ and $\mathrm{C}$, but not in a fractions $\mathrm{B}$. In the latter fraction the bands $c, i$ and $m$ were the major ones. Molecular weights of these proteins were determined for around 80000,36000 and 18500

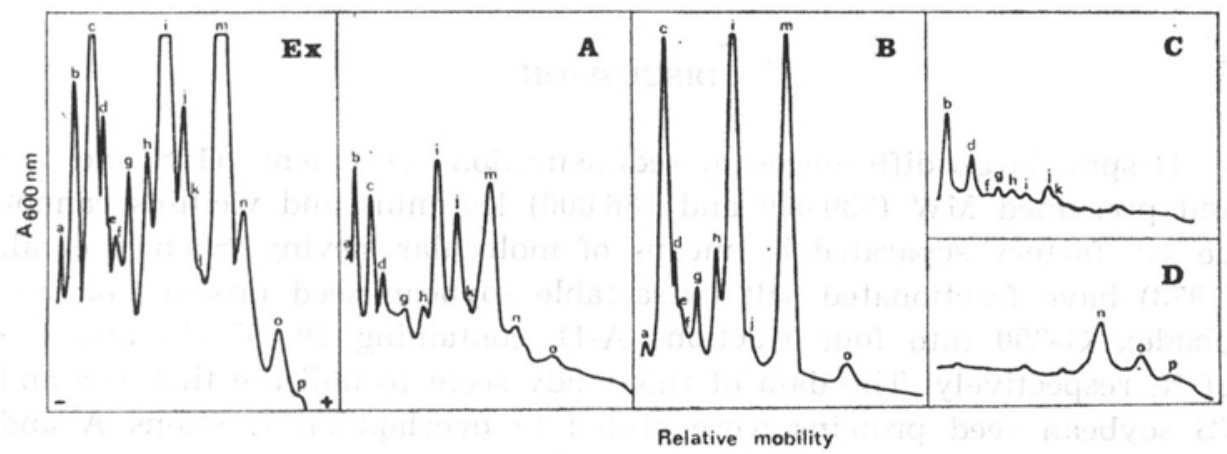

Fig. 3. Relative electrophoretic mobilities of salt extractable soybean seed proteins under dissociating conditions. Scannings were made at $6000 \mathrm{~nm}$.

Abbreviations as in Fig. 1 
daltons, respectively (Table 2). It seems that the bands $c, i$ and $m$ correspond to bands No. 6 (MW 75000 ), 17 (MW 36500 ), and 22 (MW 18500 ) on electropherograms presented by S a v o y. (1977).

Table 2

Molecular weights of protein bands detected in SDS PAGE. Relative intensity of the bands in chromatographic fractions A-D (Table 1) is denoted with $1-6+(c f$. Fig. 3).

\begin{tabular}{|c|c|c|c|c|c|}
\hline Band & $\begin{array}{c}\text { Apparent MW, } \\
\text { daltons }\end{array}$ & \multicolumn{4}{|c|}{ Presence in Sephadex G-200 fractions } \\
\hline a & 122000 & & B & C & D \\
\hline $\mathrm{b}$ & 95000 & $6+$ & - & - & - \\
$\mathrm{c}$ & 80000 & $4+$ & - & $6+$ & - \\
$\mathrm{d}$ & 70000 & + & $6+$ & - & - \\
$\mathrm{e}$ & 67000 & - & $2+$ & $3+$ & - \\
$\mathrm{f}$ & 60000 & - & \pm & - & - \\
$\mathrm{g}$ & 53000 & \pm & $2+$ & \pm & - \\
$\mathrm{h}$ & 41000 & + & $2+$ & + & - \\
$\mathrm{i}$ & 36000 & $6+$ & $6+$ & + & - \\
$\mathrm{j}$ & 27000 & $4+$ & \pm & + & \pm \\
$\mathrm{k}$ & 24000 & \pm & - & \pm & - \\
$\mathrm{l}$ & 21500 & - & - & - & $6+$ \\
$\mathrm{m}$ & 18500 & $6+$ & $6+$ & - & $3+$ \\
$\mathrm{n}$ & 13700 & + & - & - & + \\
\hline $\mathrm{o}$ & 11000 & + & + & - & - \\
$\mathrm{p}$ & 9500 & - & - & - & - \\
\hline
\end{tabular}

Protein with MW $27000(j)$ was characteristic for the fraction A. It was virtually absent in other fractions. Bands $b$ and $d$ (MW 95000 and 70000 , respectively) were the main ones in a fraction $\mathrm{C}$ in which bands $c$ (MW 80000 ) and $m$ (MW 18500) were absent. Band $n$ (MW 13700 ) was dominant in the fraction $\mathrm{D}$; it was present also in a fraction $\mathrm{A}$, and absent in fractions $\mathrm{B}$ and $\mathrm{C}$.

\section{DISCUSSION}

Despite large differences in sedimentation coefficients (11S and $7 \mathrm{~S}$ ) and presumed MW (330 000 and 186000$)$ legumins and vicillins cannot be satisfactory separated by means of molecular sieving. S a bir et al. (1973) have fractionated salt extractable soybean seed proteins on Sephadex G-200 into four fractions A-D, containing 19, 57, 11 and $1 \%$ of $\mathrm{N}$, respectively. The data of this study seem to indicate that $11 \mathrm{~S}$ and 7S soybean seed proteins were eluted in overlapping fractions $\mathrm{A}$ and B. 2.8S proteins were probably eluted in peaks C and D.

Results of electrophoretic analyses in nondissociating system support a general view that a limited number of proteins make up the bulk of 
the protein in soybean seed ( $\mathrm{H}$ i 11 and $\mathrm{Br}$ e i d e $\mathrm{n} \mathrm{b}$ a c h, 1974). Nevertheless, many other proteins are present in minor amounts; they possibly play catalytic functions (cf. Grzesiuk and $€$ uczyńska, 1972; Kulka and Grzesiuk, 1978; Millerd, 1975; S a bir et al., 1973).

Available data are inconsistent as concerns the MW of the subunits of $7 \mathrm{~S}$ globulin fraction of soybean seed. In ultracentrifuge studies the MW of the subunits was determined for 23000 and 35000 (cf. D a r b y shire, et al. 1976; Kulka and Grzesiuk, 1978). SDS PAGE gave much higher estimates of 23000,51000 and 81000 (M a s a k i and S o e j i.m a, 1972). This study revelated that three major protein bands have MW around 80000,36000 and 18500 daltons. The protein with the molecular weight of around 80000 can be, thus, regarded as one of the major component of the storage proteins of soybean seed. Basing on the data presented by $\mathrm{Mas}$ a ki and Soejima (1972) it can be suggested that protein with MW 80000 (band $c$ ) is a product of dissociation of the $7 \mathrm{~S}$ globulin.

It has been suggested that glycinins (11S) molecule is built up of equimolar amounts of acidic (MW 37000 ) and basic (MW 22000 ) subunits (C atsimpoolas et al., 1967; Catsimpoolas, 1969). This implies that in SDS PAGE there should be bands corresponding to these values of MW. Proteins $i$ (MW 36000 ) and $m$ (MW 18500) were the most intense in fractions $\mathrm{A}$ and $\mathrm{B}$. These bands are possibly components of the 11S storage globulins.

Recently S a v o y (1977) detected 28 protein bands on electropherograms of each of 21 different soybean seed varieties. Sixteen bands detected in this study fit well with S a vo y's data. Protein spectrum in the seed of soybean cultivar. 'Warszawska' seems to be similar to protein spectra of other soybean varieties.

\section{Acknowledgments}

We thank prof. dr hab. J. Szy rmer (IHAR, Radzików) for soybean seeds. This study was supported in part by IHAR under a research project PR-4/D 02-03.

\section{REFERENCES}

Catsimpoolas N., 1969. Isolation of glycinin subunits by isoelectric focusing in urea-mercaptoethanol. FEBS Lett. 4: 259-261.

Catsimpoolas N., Campbell T. G., M e yer E. W., 1969. Association-dissociation phenomena in glycinin. Arch. Biochem. Biophys. 131: 577-586.

Cat simpoolas N., R ogers D. A., C ir cle S. J., M e y e r E. W., 1967. Purification and structural studies on the $11 \mathrm{~S}$ component of soybean proteins. Cereal Chem. 44: 631.

Davis B. J., 1964. Disc electrophoresis - II. Method and application to human serum proteins. Ann. New York Acad. Sci. 121: 404-427. 
Derbyshire E., Wright D. J., Boulter D., 1976. Legumin and vicillin, storage proteins of legume seeds. Phytochemistry 15: 3-24.

Eastman SDS. Instruction Booklet for Eastman SDS Electrophoresis Reagent Set (13204). Eastman Kodak Co., Rochester, N.Y., U.S.A.

Grzesiuk S., Łuczyńska J., 1972. Nucleic acid (NA) and proteins in artificially ageing soya bean seeds (Glycine $\max$ Merr.) Bul. Acad. Pol. Sci. Ser. sci. biol. 20: 891-896.

Hill J. E., Breidenbach R. W., 1974. Proteins of soybean seeds. I. Isolation and characterization of the major components. Plant Physiol. 53: 742-746.

Knypl J. S., 1978. Electroconductivity of leaching solutes as a measure of soybean seed vigour. (In polish). Biul. IHAR (in press).

Koshiyama I., 1968. Chromatographic and sedimentation behaviour of a purified 7S protein in soybean globulins. Cereal Chem. 45: 405-412.

Kulka K., Grzesiuk S., 1978. Protein of legume seeds. (In polish). Postępy Nauk Roln. 1/166: 53-90.

Ma saki T., Soejima M., 1972. Sci. Rep. Fac. Agr. Ibaraki Univ. 20: 35 (Cit. after Derbyshire et al., 1976).

Millerd A., 1975. Biochemistry of legume seed proteins. Ann. Rev. Plant Physiol. 26: 53-72.

Os borne T. B., 1924. The Vegetable Proteins. Longmans, Green and Co., London.

Reisner A. H., Nemes P., B ucholtz C., 1975. The use of Coomassie Brillant Blue G250 perchloric acid solution for staining in electrophoresis and isoelectric focusing on polyacrylamide gels. Anal. Biochem. 64: 509-516.

Roberts R. C., Brigg S D. R., 1965. Isolation and characterization of the 7S component of soybean globulins. Cereal Chem. 42: 71-85.

Sabir M. A., Sosulski F. W., Ma c Kenzie S. L., 1973. Gel chromatography of sunflower proteins. Agr. Food Chem. 21: 988-993.

Savoy C. F., 1977. Electropherogram pattern similiarity of seed proteins from 21 different soybean (Glycine max) varieties. Can. J. Bot. 55: 2245-2250.

St ockman D. R., Ha 11 T. M., R y a n D. S., 1976. Affinity chromatography of the major protein of the bean (Phaseolus vulgaris L.). Plant Physiol. 58: 272-275.

Wolf W, 1970. Soybean proteins: Their functional, chemical, and physical properties. J. Agr. Food Chem. 230: 969-976.

\author{
Authors' address: \\ Mgr W. Lassociński and doc. dr hab. J. S. Knypl, \\ Laboratory of Plant Growth Regulators, \\ University of Łódź \\ Banacha 12/16; 90-237 Łódź; Poland
}

Elektroforeza białek nasion soi $w$ żelu poliakrylamidowym

\title{
Streszczenie
}

Białka nasion soi odm. 'Warszawska' ekstrahowano $2.5 \%$ zbuforowanym roztworem $\mathrm{NaCl}$, chromatografowano na żelu Sephadex G-200 i analizowano elektroforetycznie. Wykryto 18 pasm białkowych na elektroferogramach w układzie niedysocjującym oraz 16 pasm w układzie dysocjującym (SDS PAGE). Ciężar molowy głównych pasm białkowych wynosi 18500,36000 i 80000 daltonów. 